\title{
THE AGGL UTINATING FACTOR FOR SENSITIZED SHEEP ERYTHROCYTES IN SERUM AND JOINT FLUID FROM RHEUMATOID ARTHRITIS PATIENTS
}

\author{
BY \\ NANNA SVARTZ and KARL SCHLOSSMANN \\ From the King Gustaf $V$ Research Institute, Stockholm, Sweden
}

On May 6, 1949, a preliminary account was given before the Swedish Society for Internal Medicine of a special method for the sheep-cell agglutination test based on experiments made by the authors (Svartz and Schlossmann, 1949). A similar account was presented to the Seventh International Congress on Rheumatic Diseases, New York, 1949.

First we must emphasize the fact that all human sera contain heterophil haemagglutinins which agglutinate normal (unsensitized) red sheep cells. In certain diseases such agglutinins occur in a higher titre than in the serum of healthy persons. These heterophil agglutinins can always be absorbed by normal sheep cells.

In rheumatoid arthritis, and in isolated cases of other diseases, there exists in the blood another type of agglutinating factor, not absorbable by normal sheep cells and unable to agglutinate them. This factor only agglutinates sheep cells which have been sensitized with a small amount of rabbit anti-sheep-cell serum (amboceptor). The agglutination with normal sheep cells is inhibited by extract from the kidneys of guinea-pigs. This is not the case with the agglutination with sensitized sheep cells.

Since February, 1949, the present authors have been studying the agglutinating factor for sensitized sheep cells by an absorption method, which has not hitherto been described in detail.

\section{Absorption Method}

The fresh serum or synovial fluid under test was inactivated in a water bath for 30 minutes at $56^{\circ} \mathrm{C}$. For each test, $1.5 \mathrm{ml}$. serum or synovial fluid, $1.5 \mathrm{ml}$. packed sheep cells (obtained from fresh defibrinated blood and washed three times with sterile normal saline), and $1.5 \mathrm{ml} .0 .85$ per cent. $\mathrm{NaCl}$ solution were thoroughly mixed in a tube with a rounded bottom. The mixture was incubated in a water bath for 2 hours at $37^{\circ} \mathrm{C}$., being shaken thoroughly several times, and was then kept overnight at $4^{\circ} \mathrm{C}$. After centrifugation at 2,000 revolutions per minute for 20 minutes, the supernatant fluid was pipetted off and used for the agglutination test with normal and sensitized sheep cells.

\section{Haemagglutination Test}

Of the supernatant fluid obtained after absorption of the serum or synovial fluid with normal (unsensitized) sheep cells, two series of two-fold dilutions were made in $0 \cdot 5-\mathrm{ml}$. volumes of 0.85 per cent. $\mathrm{NaCl}$ solution.

To each tube of the first series, consisting of four tubes containing $0.5 \mathrm{ml}$. fluid (the fluid in the first of the four tubes being undiluted), was added an equal volume $(0.5 \mathrm{ml}$.) 
of 0.5 per cent. suspension of packed fresh sheep cells, washed three times in 0.85 per cent. $\mathrm{NaCl}$ solution.

To each tube of the second series, consisting of eight to twelve tubes, an equal volume $(0.5 \mathrm{ml}$.) of 0.5 per cent. suspension of sensitized, sheep cells was added. The sensitized sheep cells were produced by adding rabbit anti-sheep serum, diluted so as to contain two units, to an equal volume of a 1 per cent. suspension of sheep cells. The mixture was incubated for 15 minutes at $37^{\circ} \mathrm{C}$.

To make a homogeneous suspension of the cells the tubes of both series were thoroughly shaken and afterwards allowed to stand undisturbed in a water bath at $37^{\circ} \mathrm{C}$. for 1 hour and kept overnight at $4^{\circ} \mathrm{C}$. The reading was made after loosening clumps with a flip of the finger. The clumps in the fluid were then allowed to settle at room temperature for 30 minutes, whereupon the degree of sedimentation and clarification of the mixture were controlled.

Records of the reading were given in the following terms: 4, firm disk after tapping; 3 , disk broken into large flakes; 2 , disk easily broken into fine flakes; 1 , granular, but definite agglutination; 0 , no perceptible granularity.

The test is only valid if complete absorption of the agglutinins for normal sheep cells is established. Additional absorption with $1.5 \mathrm{ml}$. packed sheep cells was necessary in cases where the agglutinative titre for normal sheep cells was found to be exceedingly high. Sera stored in a deep-freezer at $16^{\circ} \mathrm{C}$. below for at least one year, showed no significant loss of potency.

Up to the end of May, 1950, the investigated material consisted of 463 sera and eleven joint exudates, a total of 474 , classified as follows:

\begin{tabular}{|c|c|c|c|c|}
\hline \multirow{2}{*}{ Material } & \multirow{2}{*}{ No. of Patients } & \multicolumn{3}{|c|}{ Reaction } \\
\hline & & Positive & Doubtful & Negative \\
\hline $\begin{array}{l}\text { Rheumatoid Arthritis } \\
\text { Sera fluid } \\
\text { Joint flut }\end{array}$ & $\begin{array}{r}180 \\
9\end{array}$ & $\begin{array}{r}159 \\
6\end{array}$ & $\begin{array}{r}13 \\
2\end{array}$ & $\begin{array}{l}8 \\
1\end{array}$ \\
\hline $\begin{array}{l}\text { Other Diseases and } \boldsymbol{L} \\
\text { Sera fluid } \\
\text { Joint fluid } \\
\text { (traumat.) }\end{array}$ & $\begin{array}{c}\text { ealthy Persons } \\
283 \\
2 \\
2\end{array}$ & $\begin{array}{l}10 \\
-\end{array}$ & $\begin{array}{r}106 \\
2\end{array}$ & $\begin{array}{r}167 \\
-\end{array}$ \\
\hline Total $\ldots$ & 474 & 175 & 123 & 176 \\
\hline
\end{tabular}

The agglutination is characterized as positive if the haemagglutination shows about the same titre before and after absorption with normal sheep cells. It should be mentioned that of the ten tests from diseases other than rheumatoid arthritis, which gave a positive result, three derived from patients suffering from disseminated lupus erythematosus, one from ulcerative colitis, one from serum disease, and one from heart failure; in the remaining cases the diagnosis is uncertain. In the eight cases of rheumatoid arthritis in which the reaction proved negative, our observations are still proceeding.

It is of interest to note that the sheep-cell agglutination test has given a negative result in ankylosing spondylitis. 
Concerning rheumatic fever we are not able to give a definite judgment at present. The test is always negative during the first period of the disease, but it is possible that a positive reaction can appear later, if the disease is progressive. We observed one case, where a positive test could be demonstrated two months after the onset of the disease.

Joint exudate from patients with rheumatoid arthritis has shown approximately the same strength as serum.

The authors have made a further study of the influence of ACTH (adrenocorticotrophic hormone)* or cortone (Compound E) $\dagger$ therapy upon the reaction described above. The sheep-cell agglutination is not affected by ACTH or by cortone.

\section{Summary}

A modification of the sheep-cell agglutination test is described. The method has given positive results in about 90 per cent. of cases with rheumatoid arthritis. ACTH or cortone therapy has no influence on the test.

\section{REFERENCES}

Rose, H. M., Ragan, C., Pearce, E., and Lipman, M. O. (1948). Proc. Soc. exp. Biol., 68, 1. Svartz, N. (1949). Proc. Internat. Congr. Rheum. Dis. New York, 1949. In the press.

(1950). Acta med. scand., Suppl. VII Proc. Internat. Congr. Int. Med. Paris, 1950.

- (1950). Acta med. scand., Suppl. VII Proc. Internat. Con
- , and Schlossmann, K. (1949). Nord. Med., 42, 1390.

Le Facteur d'Agglutination des Érythrocytes Sensibilisés de Mouton dans le Sérum et dans le Liquide Synovial des Malades atteints d'Arthrite Rhumatismale

\section{RÉSUMÉ}

On décrit une modification du test d'agglutination des érythrocytes de mouton. Cette méthode a donné des résultats positifs dans environ $90 \%$ des cas d'arthrite rhumatismale. Le traitement par l'hormone adrénocorticotrophique et par la cortisone n'a pas d'influence sur ce test.

\section{El Factor de Aglutinacion de Eritrocitos Sensibilizados de Oveja en el Suero $y$ en el Líquido Sinovial de Enfermos con Artritis Reumatoide}

\section{RESUMEN}

Se describe una modificación del test de aglutinación de eritrocitos de oveja. Este método dió resultados positivos en cerca de $90 \%$ de los casos de artritis reumatoide. El tratamiento por la hormona adrenocorticotrófica y por la cortisona no tuvo influencia alguna sobre el test.

\footnotetext{
* Supplied by A.B. Organon, Stockholm.

$\uparrow$ Supplied by Merck Co., U.S.A.
} 